\title{
TELAAH KRITIS FATWA MAJELIS ULAMA INDONESIA (MUI) TERHADAP PRODUK SANDANG
}

\author{
Afifatul Munawiroh, M. Khoirul Hadi al-Asy Ari \\ Institut Agama Islam Negeri (IAIN) Jember, \\ Jl. Mataram No.1, Karang Miuwo, Mangli, Kec. Kaliwates, Kabupaten Jember, \\ Jawa Timur 68136, Indonesia \\ afifatulmunawiroh93@gmail.com \\ DOI: https://doi.org/10.35719/ijl.v1i3.88
}

\begin{abstract}
This research based on Islamic Economisation in Indonesian: a Critical review of the editcts of the Majelis Ulama Indonesia (MUI) on Clothing products and their effects on the migration of life style discourse in Indonesian. In this paper there are three important questions. First, how is the history of the emergence of legal labeling in Majelis Ulama Indonesia? Second, how to develop products that are labeled halal labeling on clothing from Majelis Ulama Indonesia? Third, How the impact of halal labeling on clothing from Majelis Ulama Indonesia? With the approach of the Phemenology to expalain develop produvts that are labeled halal lebeling on clothing from Majelis Ulama Indonesia and explain the impact of halal labeling on clothing from Majelis Ulama Indonesia. And then, the history of the emergence of legal labeling in Majelis Ulama Indonesia expalain in the analysis content. The results of this study are first, to know the history of the emergence of legal labeling in Majelis Ulama Indonesia second, to know develop products that are labeled halal labeling on clothing from Majelis Ulama Indonesia third, to know the impact of halal labeling on clothing from Majelis Ulama Indonesia.
\end{abstract}

Key Words: Social Fatwa, Legal Labeling, and life Style.

Abstrak : Penelitian pada paper ini adalah penelitian yang mengkaji Ekonomisasi Agama di Indonesia: Telaah Kritis Fatwa Majelis Ulama Indonesia (MUI) Terhadap Produk Sandang dan Pengaruhnya Dengan Wacana Hijrah Life Style di Indonesia. Dalam paper ini ada tiga pertanyaan penting terkait pelabelan. 
Pertama, bagaimana sejarah munculnya pelabelan halal dalam Majelis Ulama Indonesia? Kedua, bagaimana pengembangan produk yang tertera pelabelan halal dari Majelis Ulama Indonesia? Ketiga, bagaimana dampak adanya pelabelan halal pada sandang dari Majelis Ulama Indonesia? Dengan pendekatan phemenology untuk menjelaskan pengembangan produk yang ada pelabelan halal dari Majelis Ulama Indonesia dan bagaimana dampak adanya pelabelan halal pada sandang dari Majelis Ulama Indonesia. Sedangkan sejarah munculnya pelabelan halal dalam Majelis Ulama Indonesia dijelaskan melalui konten analisis. Hasil penelitian ini adalah pertama, untuk mengetahui sejarah munculnya pelabelan halal dar Majelis Ulama Indonesia kedua, untuk mengetahui pengembangan produk yang tertera pelabelan halal dari Majelis Ulama Indonesia. ketiga, untuk mengetahui dampak adanya pelabelan halal pada sandang dari Majelis Ulama Indonesia.

Kata Kunci : Fatwa Sosial, Label Halal, dan Life Syle

\section{Pendahuluan}

Distribusi sandang di Indonesia berjalan sejak dulu kala. Bisa dibilang sejak zaman penajajahan sudah ada distribusi sandang seperti baju, celana, dan sewek terbatas. Untuk itu, pemerintah mendirikan badan-badan pemerintahan dalam mengelola semua permasalahan masyarakat. Tentunya mengurus permasalahan yang menyangkutpautkan dengan hukum Islam, yaitu Majelis Ulama Indonesia. Permasalahan yang sering diperbincangkan masyarakat zaman sekarang adalah hukum dari makanan atau pun benda yang halal dan haram. Kekhawatiran muncul pada benda yang najis tidak akan bisa dikonsumsi dengan halal. Adanya kehawatiran itu menjadikan beberapa pengusaha distribusi kerudung marak 
meminta pelabelan halal untuk produk mereka kepada Majelis Ulama Indonesia. Namun, masyarakat terkadang tidak menghiraukan pelabelan halal tersebut.

Tujuan pelaksanaan pelabelahan halal untuk memberikan kepastian kehalalan suatu produk sehingga dapat mententeramkan batin bagi konsumen. Adanya sertifikasi halal menunjukkan terdapat perlindungan terhadap kepentingan umat muslim. Perlindungan tersebut mununjukkan kandungan hukum yang dibuat oleh agama telah tereduksi dan kurang kuat dalam mengatur hubungan yang lebih nyata dalam kehidupan bernegara. Fenomena tersebut disebabkan beberapa hal. Misalnya di negara-negara sekuler, nilai-nilai yang terkandung dalam agama tidak lagi menjadi pertimbangan dalam perumusan kebijakan atau undang-undang. Sebab, agama menjadi urusan personal atau urusan warga negaranya secara perorangan. ${ }^{1}$

Melimpah ruahnya bahan sandang di Indonesia menjadikan masyarakat tergiur untuk membuka bisnis menjahit baju home stay atau pun konveksi sehingga muncul segala jenis sandang yang ekonomis. Adapun konsumen kelas bawah sering tergiur barang ekonomis tanpa melihat bahan yang digunakan dalam pembuatan pakaian tersebut. Kejadian ini, muncul beberapa pertanyaan tentang kehalalan suatu 
sandang yang dikenakan itu halal atau haram. Di sinilah, distributor yang mengajukan label halal untuk barang yang didistribusikannya. Lantas, bukankah seperti itu masuk dalam ekonomisasi agama?

Konsumen kelas menengah muslim di Indonesia mengalami pergeseran model pakaian yang sangat fundamental dalam beberapa tahun terakhir ini. Apabila diamati tren yang berkembang selama sepuluh tahun terakhir dari waktu ke waktu dapat dilihat bahwasanya para konsumen mementingkan aspek religi dalam sandangnya. Hal yang menarik dari fenomena ini adalah meningkatnya kereligiusitas yang tidak tampak dalam konteks ritual ibadah saja, tetapi juga dalam kehidupan sehari-hari misalnya mengkonsumsi produk. Bagi konsumen, kini konsumsi produk ditempatkan sebagai bagian upaya menjalankan perintah Tuhan dan menjauhi larangan-Nya. Sebagai salah satu busana ritual keagamaan, kerudung, siwak, dan mukenah ber-merk merupakan salah satu dari bagian tersebut. ${ }^{2}$

Selain merek, persoalan lain konsumen dalam memilih produk adalah label halal dalam kegunannya untuk memutuskan keraguan konsumen terhadap produk yang dihasilkan produsen. Keraguan ini terjadi lantaran pelaku pasar dalam dunia industri terdiri dari produsen yang

${ }^{2}$ Nurul, Istiqomah. 2016. "Mengungkap Mitos Simbol Halal pada Kerudung Zoya di Instagram”. Semarang. Skripsi, Jurusan Ilmu Komunikasi Fakultas Ilmu Sosial dan Politik Universtas Diponegoro. Hlm: 3 
memilikii tingkat kemajemukan yang tinggi baik dari sisi suku, agama, latar belakang sosial dan ekonomi serta pendidikan. tingkat kemajemukan ini disiasati oleh produsen dengan membuat spesifikasi atau aspek pembeda (differensiasi) dengan mencantumkan label halal dalam kemasan produk agar lebih meyakinkan segmen pasar. Majelis Ulama Indonesia menetapkan produk halal adalah produk yang memenuhi syarat kehalalan sesuai dengan syariat Islam, dengan rincian tidak mengandung bahan yang berusmber dari babi, bahan-bahan yang berasal dari organ manusia, darah, dan kotoran ${ }^{3}$ yang menyebabkan terhindarnya dengan bahan tersebut, maka diberi label halal.

Dari sini menimbulkan konflik dan permasalahan yang baru tentang adanya label halal yang diberikan Majelis Ulama Indonesia yang melibatkan barang gunaan dengan merek Zoya yang diproduksi oleh PT Shafco Multi Trading. Selain seleksi dari Majelis Ulama Indonesia, sebenarnya ada lembaga yang bernama Lembaga Advokasi Halal (Indonesia Halal Watch) yang didirikan di Jakarta pada tanggal 23 Januari 2013 berdasarkan Akta Notaris Zainudin, S.H., Nomor 48 dan telah disahkan Kementerian Hukum dan HAM dengan Nomor AHU-0014590.AH.01.07.Tahun 2015, hadir sebagai partisipasi

3Siti, Maemonah. 2017. "Pengaruh Merk dalam Labelisasi Halal Terhadap Keputusan Pembelian Produk Jilbab Zoya: Studi Kasus Pada Konsumen di Outlet Produk Jilbab Zoya Pamularsih Semarang”. Skripsi Program Studi Ekonomi Islam Fakultas Ekonomi dan Bisnis Islam Universitas Islam Negeri Walisongo Semarang. Hlm 4-5 
masyarakat dalam mengawali implementasi Undang-Undang Nomor 33 Tahun 2014 Tentang Jaminan Produk Halal (UU JPH). Lembaga tersebut sebagai jembatan penghubung masyarakat, konsumen, pelaku usaha dan pemerintah dalam implementasi dan law enforcement UU JPH. Kehadiran Indonesia Halal Watch diperlukan bagi masyarakat konsumen dan produsen menyonggong tahun 2019, pelaku usaha wajib melakukan sertifikasi Halal. ${ }^{4}$ Adanya permasalahanpermasalah di atas mengundang penulis untuk mengungkap kontroversi terkait label halal dalam sandang.

\section{Pembahasan}

\section{Sejarah Pelabelan Halal Oleh Majelis Ulama Indonesia}

Majelis Ulama Indonesia berdiri sebagai hasil dari pertemuan atau musyawarah para ulama, cendekiawan dan zu'ama yang datang dari berbagai penjuru tanah air. Dari musyarawah tersebut, dihasilkan sebuah kesepakatan untuk membentuk wadah tempat bermusyawarahnya para ulama. Dari musyawarah tersebut ada fatwa yang menyatakan kriteria produk halal.

Pembentukan LPPOM MUI didasarkan atas mandat dari pemerintahan agar Majelis Ulama Indonesia berperan aktif dalam meredakan kasus lemak babi di Indonesia pada tahun 
1988. LPPOM MUI didirikan pada tanggal 6 Januari 1989 untuk melakukan pemeriksaan dan sertifikasi halal. Untuk memperkuat posisi LPPOM MUI menjalankan fungsi sertifikasi halal, maka pada tahun 1996 di tandatangani nota kesepakatan kerjasama antara Departemen Agama, Departemen Kesehatan dan MUI. Dalam proses dan pelaksanaan sertifikasi halal, LPPOM MUI melakukan kerjasama dengan Badan Pengawasan Obat dan Makanan (BPOM), Kementerian Agama, Kementerian Pertanian, Kementerian Koperasi dan UKM, Kementerian Perdagangan, Kementerian Perindustrian, Kementerian Kelautan dan Perikanan, Kementerian Pariwisata dan Ekonomi Kreatif serta sejumlah Perguruan Tinggi di Indonesia antara lain Institut Pertanian Bogor (IPB), Universitas Muhammadiyah Dr. Hamka, Universitas Djuanda, UIN, Universitas Wahid Hasyim Semarang, serta Universitas Muslimin Indonesia Makassar. Sedangkan kerjasama dengan lembaga telah terjalin dengan Badan Standarsasi Nasional (BSN), Kadin Indonesia Komite Timur Tengah, GS1 Indonesia, dan Research in Motion (Blacberry). Khusus dengan BPOM, sertifikat halal MUI merupakan persyaratan dalam pencantuman label halal pada kemasan produk yang beredar di Indonesia.

Sejak saat ini usianya yang ke-3o tahun, LPPOM MUI menjadi lembaga sertifikasi halal pertama dan terpecaya di Indonesia serta semakin menunjukkan eksistensinya sebagai 
lembaga sertifikasi halal yang kredibel, baik di tingkat nasional maupun internasional. Pada tahun 2017 dan 2018 LPPOM MUI memperoleh sertifikasi akreditasi SNI ISO/IEC 17025: 2008 untuk Laboratorium Halal dan SNI ISO/IEC 17065: 2012 dan DPLS 21 untuk lembaga sertifikasi halal dari Komite Akreditasi Nasional (KAN). Standar ini tidak hanya diakui di Indonesia, namun juga diakui oleh Badan Akreditasi Uni Emirat Arab atau ESMA.

Pada januari 2019 LPPOM MUI, bekerja sama dengan berbagai pihak yang telah membangun dan meresmikan laboratorium halal di dua lokasi, yakni kawasan industri Modern Cikande, Banten, dan di kawasan Deltamas, Cikarang Jawa Barat. Laboratorium halal tersebut diharapkan dapat semakin meningkatkan layanan LPPOM MUI kepada langanan industry yang memerlukan jasa laboratorium. Sistem sertifikasi lain dan sistem jaminan halal yang dirancang serta diimplementasikan oleh LPPOM MUI telah diakui oleh lembaga-lembaga sertifikasi halal lura negeri, yang kini mencapai 45 lemaga dari 26 negara. ${ }^{5}$

Awal mula penetapan produk halal ini pada Komisi Fatwa Majelis Ulama Indonesia dalam rapat Komisi bersama LPPOM MUI, pada hari Rabu dan Sabtu, tanggal 17 dan 20 Ramadhan $1421 \mathrm{H} / 13$ dan 16 Desember 2000 M. setelah menimbang 
beberapa masalah yaitu, 1. Bahwa makanan, minuman, obatobatan, kosmetika, dan lain-lain yang akan dikonsumsi atau dipergunakan oleh umat Islam wajib diperhatikan dan diyakini kehahalan dan kesuacianya, 2. Bahwa produk makanan, minuman, obat-obatan, kosmetika dan lain-lain merupakan hasil olahan sering diragukan kehalalan atau kesucianya, 3. Bahwa oleh karena itu, produk-produk olahan yang terhadapnya telah dilakukan pemeriksaan, penelitian, pembahasan, dan penilaian dalam rapat Komisi Fatwa bersama LPPOM MUI, dipandang perlu untuk menetapkan kehalalan dan kesucian untuk dijadikan pedoman oleh umat.

Menimbang "hukum asal dari suatu masalah yang bermanfaat adalah boleh dan hukum asal sesuatu yang berbahaya adalah haram". Majelis Ulama Indonesia memutuskan untuk menetapkan fatwa tentang penetapan beberapa produk halal, yaitu 1. Produk-produk sebagaimana tersebut dalam lampiran fatwa ini ditetapkan kehalalan dan kesuciannya, 2. Keputusan ini berlaku sejak ditetapkan, dengan ketentuan jika kemudian hari ternyata terdapat kekeliruan, akan diperbaiki dan disempurnakan sebagaimana mestinya. ${ }^{6}$

Setelah itu, fatwa dari Majelis Ulama Indonesia standardisasi fatwa halal keputusan Rakos Komisi fatwa dan

${ }^{6}$ Sejarah Majelis Ulama Indonesia (MUI) dikutip dari www.mui.or.id pada tanggal 1 Juli 2019 pukul 14.10 wib 
LPPOM MUI serta departemen Agama, pada 25 Mei 2003. Lanjut dan memustuskan beberapa bahan yaitu masalah penggunaan nama dan bahan bahwa 1. Tidak boleh mengkonsumsi dan menggunakan nama atau simbol-simbol makanan atau minuman yang mengarah kepada kekufuran dan kebatilan, 2. Tidak boleh mengkonsumsi dan menggunakan nama atau simbol-simbol makanan/minuman yang mengarah kepada nama-nama atau simbol-simbol makanan/minuman yang mengarah kepada nama-nama benda/binatang yang diharamkan terutama babi dan khamr, kecuali telah mentradisi ('urf) dan dipastikan tidak mengandung unsur-unsur yang diharamkan seperti nama bakso, bakmi, bakwan, bakpia, dan bakpao, 3. Tidak boleh mengkonsumsi dan menggunakan bahan campuran bagi komponen makanan/minuman yang menimbulkan rasa/aroma (flavour) benda-benda atau binatang yang diharamkan, seperti mie instan rasa bai, bacon flavour, 4 . Tidak boleh mengkonsumsi makanan/minuman yang menggunakan nama-nama makanan/minuman yang diharamkan seperti whisky, brandy dan beer. ${ }^{7}$

Sertifikat halal dan labelisasi halal merupakan dua kegiatan yang berbeda tetapi mempunyai keterkaitan satu sama lain. Hasil dari kegiatan halal adalah diterbitkannya

7Sejarah Majelis Ulama Indonesia (MUI) dikutip dari www.mui.or.id pada tanggal 1 Juli 2019 pukul 14.33 wib 
sertifikat halal, apabila produk yang dimaksud-kan telah memenuhi ketentuan sebagai produk halal. Sertifikasi halal dilakukan oleh lemabga yang mempunyai otoritas untuk melaksanakannya. Tujuan akhir dari sertifikasi halal adalah pengakuan secara legal bahwa produk yang dikeluarkan telah memenuhi ketentuan halal. Sedangkan labelisasi halal adaah pencantuman tulisan atau pernyataan halal adalah pencantuman tulisan atau peryataan halal pada kemasan produk untuk menunjukkan bahwa produk yang dimaksud berstatus sebagai produk halal. ${ }^{8}$

Bagi konsumen, sertifikat halal memiliki beberapa fungsi. Pertama, terlindunginya konsumen muslim dari mengonsumsi pangan, obat-obatan dan kosmetika yang tidak halal. Kedua, secara kejiwaan perasaan hati dan batin konsumen akan tenang. Ketiga, mempertahankan jiwa dan raga dari keterpurukan akibat produk haram. Keempat, akan memberikan kepastian dan perlindungan hukum. Bagi produsen, sertifikat halal mempunyai beberapa peran penting. Pertama, sebagai dipertanggungkan produsen kepada konsumen muslim, mengingat masalah halal merupakan bagian dari prinsip hidup muslim. Kedua, meningkatkan kepercayaan dan kepuasan konsumen. Ketiga, meningkatkan citra dan daya saing perusahaan dan keempat, sebagai alat

${ }^{8}$ Sofyan Hasan, "Kepastian Hukum Sertifikasi dan Labelisasi Halal Produk Pangan", Jurnal Dinamika Hukum, Volume 14 Nomor 2, 2 Mei 2014, Palembang: Universitas Sriwijaya, hlm: 231. 
pemasaran serta untuk memperluas area jaringan pemasaran. Kelima, memberi keuntungan pada produsen dengan meningkatkan daya saing dan omzet produksi dan penjualan. ${ }^{9}$

Majelis Ulama Indonesia dalam menetapkan suatu fatwa terlebih dahulu mempelajari setiap konflik yang disampaikan kepada Majelis Ulama Indonesia dengan saksama sekurangkurangnya seminggu sebelum disidangkan. Jika sudah jelas persoalan sesuai hukum yang qathy'i, hendaklah komisi menyampaikan sebagaimana adanya dan fatwa menjadi gugur setelah diketahui nash-nya dari Al-Quran dan sunnah. Sedangkan dalam masalah yang terjadi khilafiyah (perbedaan pendapat) di kalangan madzab, maka yang difatwakan adalah hasil tarjih setelah memperhatikan fikih muqaran (perbandingan) dengan menggunakan kaidah-kaidah ushul fiqih muqaran yang berhubungan dengan pentarjihan.

Setelah melakukan pembahasan, secara mendalam dan komprehensif, serta memperhatikan pendapat dan pandangan yang berkembang dalam sidang, komisi menetapkan fatwa. Setiap keputusan fatwa harus di-tanfidz-kan setelah ditandatangani oleh Dewan Pimpinan dalam bentuk Surat Keputusan Fatwa (SKF). Di dalam SKF, harus dicamtumkan dasar-dasar pengambilan hukum disertai uraian dan analisis secara ringkas, serta sumber pengambilannya. Demikian pula 
SKF sedapat mungkin disertai dengan rumusan tindak lanjut dan rekomendasi atau jalan keluar yang diperlukan sebagai konsekuensi dari SKF tersebut. Majelis Ulama Indonesia, secara hierarkis ada dua, yaitu Majelis Ulama Indonesia Pusat yang berkedudukan di Jakarta dan Majelis Ulama Indonesia daerah.

Majelis Ulama Indonesia Pusat berwenang dan mengeluarkan fatwa mengenai permasalahan keagamaan yang bersifat umum dan menyangkut permasalahan umat Islam Indonesia secara nasional dan masalah keagamaan yang terjadi di daerah, namun efek yang terjadi dapat meluar ke daerah lain. Bahkan, masalah-masalah tersebut bisa menyeluruh. Meskipun ada hierarki antara MUI pusat dan MUI daerah, namun fatwa yang dikeluarkan kedua lembaga tersebut adalah sederajat, artinya bahwa fatwa yang satu tidak bisa membatalkan fatwa yang lain. Masing-masing fatwa berdiri sendiri sesuai dengan lokalitas dan kondisinya. Namun, ketika keputusan MUI Daerah dan MUI Pusat ada perbedaan dalam masalah yang sama, maka kedua pihak bertemu untuk mencari penyelesaian yang terbaik agar keputusan tersebut tidak membingungkan umat Islam. ${ }^{10}$

\footnotetext{
${ }^{10}$ Khoirul, Hadi dan Afifatul, Munawiroh. 2019. "Dari Fatwa Preventif Menuju Fatwa Advokatif: Menggagas Metodologi Penetapan Fatwa Majelis Ulama Indonesia Menggunakan Prinsip Keterbukaan Fatwa (Fath Az-Zari'ah) dan Kritik Terhadap Fatwa MUI yang Menggunakan Prinsip Pencegahan dalam Fatwa (Sadd Az-Zari'ah) yang Berkaitan dengan Hukum Keluarga”. Jember. Jurnal Fakultas Syariah IAIN Jember. Hlm: 16-18.
} 


\section{Pengembangan Produk yang Tertera Label Halal dari}

\section{Majelis}

Label halal yang tercantum pada sejumlah barang dagangan terutama sandang, membuat konsumen menjadi lebih yakin dengan yang dibeli atau dikonsumsinya. Karena konsumen sudah percaya bahan produk yang mereka konsumsi sudah halal dan ditetapkan langsung oleh Majelis Ulama Indonesia. Dari data Lembaga Pengkajian Pangan Obat-obatan dan Kosmetika Majelis Ulama Indonesia (LPPOM MUI), baru sekitar 623.264 UMKM telah mendapat sertifikat halal dari MUI. Padahal dari data Badan Pusat Statistik (BPS), angka UMKM di Indonesia mencapai empat juta. Lantas, Ketua Umum Majelis Ulama Indonesia KH. Ma'ruf Amin mengatakan, pemberian sertifikasi merupakan peluang bagi UMKM untuk mengembangkan bisnisnya. Hal ini bukanlah persoalan baru bagi pelaku UMKM. Pemberian sertifikat dari MUI merupakan satu terobosan baru bagi UMKM dalam menambah kepercayaan bagi konsumen. Selain itu, kesadaran akan produk halal di dunia semakin besar sehingga peluang menambah pasar global makin terbuka. ${ }^{11}$

Proses sertifikasi halal yang dilakukan oleh Majelis Ulama

\footnotetext{
"Undang-Undang jaminan Produk Halal 2019 dikutip dari https://www.inews.id/travel/belanja/uu-jaminan-produk-halal-bukanlahpenghambat-perkembangan-umkm/313058 pada tanggal 2 juli 2019 pukul 09.07 wib. 9 Sofyan Hasan, "Kepastian Hukum Sertifikasi dan Labelisasi Halal Produk Pangan", Jurnal Dinamika Hukum, Volume 14 Nomor 2, 2 Mei 2014, Palembang: Universitas Sriwijaya, hlm: 232.
} 
Indonesia yang melalui LPPOM MUI dan komisi fatwa melalui tahapan konstruksi pikir yang merupakan kewajiban untuk mengarahkan hukum kepada cita-cita yang diinginkan masyarakat, dalam hal ini konsumen dan pelaku usaha. Meminjam istilah Rudolf Stamler inilah yang disebut dengan cita hukum. Cita hukum tersebut ialah pokok-pokok pikiran yang terkandung dalam Pembukaan Undang-Undang Dasar 1945 cita hukum tersebut tidak lain ialah pancasila.

Selain itu, pancasila telah ditetapkan para pendiri negara Proklamasi ini sebagai norma tertinggi dalam kehidupan kenegaraan rakyat Indonesia, sebagai norma dasar negara (staatsgrundnorm). Cita hukum berfungsi sebagai "bintang pemandu" bagi tercapainya cita-cita masyarakat. Meskipun merupakan titik akhir yang tidak mungin dicapai, namun cita hukum memberi manfaat karena ia yang berlaku, dan kepada cita hukum dapat mengarahkan hukum positif sebagai usaha mengatur tata kehidupan dengan sanksi pemaksa, mmenuju suatu yang adil. Oleh karena itu, menurut Stammler, keadilan ialah usaha atau tindakan mengarahkan hukum positif cita hukum. ${ }^{12}$ (baik secara perdata maupun pidana) yang jelas diatur dalam produk hukum, misal undang-undang atau pencabutan izin usaha.

\footnotetext{
"Sofyan Hasan, "Kepastian Hukum Sertifikasi dan Labelisasi Halal Produk Pangan", Jurnal Dinamika Hukum, Volume 14 Nomor 2, 2 Mei 2014, Palembang: Universitas Sriwijaya, hlm: 231.

${ }^{12}$ Lies Afroniyati, 2014,"Analisi Ekonomi Politik Sertifikasi Halal oleh Majelis Ulama Indonesia", Yogyakarta, Jurnal Kebijakan dan Administrasi Publik, hlm: 40.
} 
Dalam hal ini, Majelis Ulama Indonesia memang mempunyai beberapa kelemahan sebagi lembaga kontrol dan pengawasan atas peredaran produk halal di pasar. Fungsi kontrol dan pengawasan LPPOM Majelis Ulama Indonesia tidak semaksimal disebabkan tidak adanya perangkat lain yang menyertai. LPPOM Majelis Ulama Indonesia tidak bisa berbuat lebih ketika terjadi pelanggaran-pelanggaran yang dilakukan oleh para pengusaha dengan memperbanyak label halal secara ilegal. LPPOM Majelis Ulama Indonesia juga tidak bisa emaksakan semua produsen untuk mendaftarkan tiap produknya ke Majelis Ulama Indonesia. Hal ini dikarenakan tidak adanya sanksi atau hukuman. ${ }^{13}$

Dalam pengajuan label halal ada prosedur dan penetapan mekanisme fatwa, sama dengan penetapan fatwa secara umum. Hanya saja, sebelum masalah tersebut (produk yang dimintakan fatwa halal) dibawa ke dalam sidang Komisi LPPOM MUI untuk dilakukan penelitian dan audit ke pabrik yang bersangkutan. Untuk itu, prosedur dan mekanisme penetapan fatwa halal, secara singkat dapat dijelaskan sebagai berikut: Pertama, Majelis Ulama Indonesia memberikan pembekalan pengetahuan kepada para auditor LPPOM tentang benda-benda haram menurut syariat islam. Dalam hal ini benda haram li-zatihi dan haram li-ghairihi yang karena cara penanganannya tidak sejalan dengan syariat islam. 
Dengan artian, para auditor harus mempunyai pengetahuan memadai tentang benda-benda tersebut. Kedua, para auditor melakukan penelitian dan audit ke pabrik pabrik (perusahaan) yang meminta sertifikasi halal dan melakukan pemeriksaan.

Ketiga, pemeriksaan terhadap suatu perusahaan tidak jarang dilakukan lebih dari satu kali, dan tidak jarang pula auditor LPPOM menyarankan bahkan mengharuskan agar mengganti suatu bahan yang dicurigai atau diduga mengandung bahan yang haram dengan bahan yang diyakini halalnya atau sudah bersertifikasi halal dari Maajelis Ulama Indonesia atau dari lembaga lain yang dipandang berkompeten, jika perusahaan tersebut menginginkan mendapat sertifikat halal dari Maajelis Ulama Indonesia. Keempat, hasil pemeriksaan dan audit LPPOM tersebut kemudian dituangkan dalam sebuah berita acara dan kemudian berita acara itu diajukan ke komisi fatwa Majelis Ulama Indonesia untuk disidangkan. Kelima, dalam sidang komisi fatwa, LPPOM menyampaikan dan menjelaskan isi berita acara dan kemudian dibahas secara teliti dan mendalam oleh sidang komisi

Keenam, suatu produk yang masih mengandung bahan yang diragukan kehalalannya atau terdapat bukti-bukti pembelian bahan produk yang dipandag tidak transparan oleh sidang komisi dikembalikan kepada LPPOM untuk dilakukan 
penelitian atau auditing ulang ke perusahaan yang bersangkutan. Ketujuh, sedangkan produk yang telah diyakini kehalalanya oleh sidang komisi, diputuskan fatwa halalnya oleh sidang komisi. Kedelapan, hasil sidang komisi yang berupa fatwa halal dilaporkan kepada Dewan Pimpinan Majelis Ulama Indonesia untuk dikeluarkan surat keputusan fatwa halal dalam bentuk sertifikat halal. Untuk menjamin kehalalan suatu produk yang telah mendapat sertifikat halal, Majelis Ulama Indonesia menetapkan dan menekankan bahwa jika sewaktu-waktu ternyata diketahui produk tersebut mengandung unsur-unsur bahan haram (najis), maka Majelis Ulama Indonesia berhak mencabut sertifikat halal yang bersangkutan. ${ }^{14}$

Dalam pengembangan labelisasi halal ada jaminan dari produk tersebut. Jaminan suatu produk halal memerlukan sistem yang memuat jaminan kehalalan, baik yang ditinjau dari sisi bahan baku dan turunannya maupun proses dari produksinya. Sistem Jaminan Halal (SJH) adalah suatu sistem yang dibuat dan dilaksanakan oleh perusahaan pemegang sertifikat halal dalam rangka menjamin kesinambunngan proses produksi halal. Sistem ini dibuat sebagai bagian dari kebijakan suatu sistem yang berdiri sendiri sehingga produk yang dihasilkan dapat dijamin kehahalanya oleh LPPOM

${ }^{14}$ Sejarah Majelis Ulama Indonesia (MUI) dikutip dari www.mui.or.id pada tanggal 2 Juli 2019 pukul 15.14 wib 
Majelis Ulama Indonesia. ${ }^{15}$

Dalam pengembangan bisnis sandang yang diberi label halal oleh Majelis Ulama Indonesia mejadikan sebagian pengusaha industri merasa di untungkan. Karena konsumen percaya terhadap produk yang dikonsumsinya sudah diseleksi secara mutakhir oleh Majelis Ulama Indonesia. Posisinya sebagai pengusaha akan terus berjaya jika para konsumen memilih sandang yang diberi label halal oleh Majelis Ulama Indonesia. Hal ini juga berlaku pada merek pasta gigi yang mencampur bahan-bahannya dengan kayu untuk bersiwak, produk ini menawarkan pasta gigi dengan sunnah nabi untuk bersiwak. Dengan iklan yang menyatakan bahwasanya pasta gigi ini bagus dan menarik minat kaum muslim yang berbondong-bondong hijrah melalu islam sosial media.

Dalam pencantuman label halal banyak sekali yang menyinggung para produsen menengah yang tidak mencantumkan label hala dalam distribusinya. Menjadikan laju distribusinya tidak cemerlang seperti halnya produsen baju atau barang yang mencantumkan lalabel halal pada produknya. Lantas, banyak yang menghakimi bahwasanya adanya label halal adalah sangat cocok digunakan bagi muslim yang menjaga muru'ah sebagai kaum muslim. Hal ini bertentangan dengan mukena syar'i syahrini yang dihargai

${ }^{15}$ Sofyan Hasan, "Kepastian Hukum Sertifikasi dan Labelisasi Halal Produk Pangan", Jurnal Dinamika Hukum, Volume 14 Nomor 2, 2 Mei 2014, Palembang: Universitas Sriwijaya, hlm: 232-232. 
dengan mukena high class fantastis. Walaupun dalam pemasaran mukena tersebit tidak mencantumkan label halal dari Majelis Ulama Indonesia.

\section{Dampak Pelabelan Halal Sandang dari Majelis Ulama Indonesia}

Pencantuman label halal produk dilakukan untuk memberikan perlindungan kepada konsumen muslim, dikarenakan permasalahan labelisasi halal pada beberapa produk yang mengandung bahan-bahan yang haram untuk dikonsumsi. Dari sini dapat menyinggung kasus produk hijab dari PT Shafco yaitu jilbab Zoya yang menguji kehalalan produk jilbabnya. Proses produksi diperlukannya ketentuanketentuan syarat kehalalan produk secara syara. Dengan adanya label halal yang tercantum pada kemasan produk, maka secara langsung memberikan pengaruh bagi konsumen khususnya masyarakat muslim untuk menggunakan produk tersebut. Munculnya rasa aman dan nyaman dalam mengonsumsi produk tersebut meninggkatkan kepercayaan serta minat pembelinya. ${ }^{16}$

Sedikit banyak usaha Majelis Ulama Indonesia mempertahankan penerbitan sertifikasi halal didukung perkembangan identitas dan simbol perjalanan Islam yang menguat pasca reformasi. Meskipun sedari awal, hak

\footnotetext{
${ }^{16}$ Yuli Mutiah Rambe dan Syaad Afifudin, 2012, "Pengaruh Pencantuman Label Halal Pada Kemasan Mie Instan Terhadap Minat Pembelian Masyarakat Muslim", Desember 2012, Jurnal Ekonomi dan Keuagan, hlm: 39
} 
penerbitan sertifikasi halal mengalami kontroversi terus menerus, tetapi dukungan terhadap adanya sertifikasi halal terus tergalang. Sedang Majelis Ulama Indonesia sebagai pihak yang menerbitkan sertifikat mendapat posisi khusus yang menguntungkan dari publik. Simbolisasi islam menguat dalam budaya kultural Indonesia semakin memungkinkan untuk tumbuh suburnya produk halal. ${ }^{17}$ Jadi adanya labelisasi mempunyai keuntungan yang melimpah bagi produsen sandang.

Label halal tidak selalu menjamin kehalalan produk yang berada dalam kemasan. Penyalahgunaan logo halal juga sering dilakukan produsen-produsen "curang”. Kecurangan berupa pengganti komposisi bahan setelah mendapatkan sertifikat halal atau memalsukan logo halal pada prokduknya (bagi produsen yang belum memperoleh sertifikasi halal dari Majelis Ulama Indonesia. Pemalsuan ini dilatarbelakangi beberapa kemungkinan antara lain: 1) sistem birokrasi yang terlalu prosedural. 2) kontol dari pemerintah atau pihak yang berwenang terlalu longgar. 3) Undang-undang yang lemah. Beberapa konsumen harus tetap waspda dan berhati-hati ketika membeli suatu produk. Selain label halal, kemasan produk perlu pencantuman tanggal kadaluarsa (expired date) pada pasta gigi siwak dan nomor registrasi dari BPPOM atau 
Depkes yang memberikan jaminan bahwa produk aman bagi tubuh dan tidak membahayakan kesehatan. ${ }^{8}$

Pencantuman label halal terhadap pakaian merupakan hal yang baik, namun banyaknya produsen yang kontra akibat kejadian ini menyebabkan timbul dampak buruk pada pencantuman label halal. Memang dapat dibuktikan bahwasanya label halal Majelis Ulama Indonesia bisa memperluas jaringan distribusinya. Tetapi banyak pihak produsen menengah yang dirugikan lantaran mengajukan label halal ke Majelis Ulama Indonesia membutuhkan dana yang cukup banyak. Apalagi maraknya para new hijrah muslim yang hanya mengkaji agama dalam ranah konteks semata. Hal ini menjadikan pihak produsen yang mencantumkan label halal menjadi diuntungkan karena banyak pesanan sandang akibat dari label halal.

Tidak bisa dipungkiri juga adanya siwak yang dalam iklannya bisa memperlancar proses berhijrah. Itu semua hanya alih-alih yang digunakan untuk mencari keuntungan semata dengan labelisasi keagamaan. Hal ini semakin berdampak pada pembubaran cara berfikir yang islami. Muslim sosial media nantinya hanya memutuskan seluruh keimanan islamnya hanya terbatas pada pakaian (sandang) yang dikenakannya. Karena pemikiran yang masih baru-baru

${ }^{18}$ Dampak Produk Tanpa Label Halal Dalam Membuat Keputusan Pembelian Produk Kosmetik: Studi pada Konsumen Swalayan Aneka Jaya Ngaliyan Semarang, dikutip di walisongo.ac.id pada tanggal 3 Juli 2019 pukul $12.02 \mathrm{wib}$ 
mengenal religiusitas.

Dilihat dari kritik hermeneutis atas fatwa Majelis Ulama Indonesia, ada fatwa yang berbicara mengenai pluralisme agama. Namun fatwa itu tidak bisa secara merta diyakini sebagai sebuah kebenaran mutlak. Sebab, fatwa hasil dari proses penalaran dan pemahaman para pemberi fatwa atas ayat-ayat Al-Quran dan hadist nabi. Sebuah hasil proses penalaran dan pemahaman, nilai atau tingkat kebenaran yang ada di dalam teks-teks keagamaan islam yang dijadikan sebagai sumber fatwa. ${ }^{19}$

Hal yang lebih baik diajukan adalah pencantuman label haram bagi beberapa sandang yang disinyalir terdapat bahanbahan dari produk yang menggunakan bahan haram. Adanya pelabelan haram pada sandang menjadikan para warga tidak harus ketakutan atau cidera dalam memilih sandang yang konsumen manfaatkan. Karena dalam penggunaan sandang jarang terdeteksi adanya bahan haram yang digunakan sebagai produk dari produksinya. Hal ini bisa meminimalir terjadinya kehidupan style mode sandang, hijab yang bersifat ekonomisasi keagamaan. Karena jumlah produsen yang memproduksi sandang dari bahan haram hanya minoritas bahkan jarang untuk ditemui. Untuk itu, label haram hanya digunakan pada sandang yang telah terdeteksi bahan haram.

${ }^{19}$ Fuad Mustafid, 2014, "Ketika Makkah Menjadi Las Vegas Agama, Politik, dan Ideologi”, Jakarta, PT Gramedia Pustaka Umum, hlm: 170. 


\section{Kesimpulan}

Pengembangan label halal Majelis Ulama Indonesia bekerja sama dengan LPPOM MUI yang menguji seluruh obat-obatan, pangan, dan kosmetika agar terhindar atau terlindung dari bahan-bahan haram. Dalam uji kehalalan makanan memang LPPOM Majelis Ulama Indonesia sangat berpengaruh, karena benar-benar bisa menjamin bahan dari makanan yang akan didistribusikan oleh produsen kepada konsumen. Permasalahan label halal ini merujuk pada sandang seperti kerudung, mukenah, dan gamis. Masalah itu kiranya sangat menarik untuk difatwakan karena sangat sedikit kemungkinan ditemukannya produk haram dalam sandang. Label halal juga menguntungkan bagi produsen yang menantumkan label halal pada produknya, di era ini sebagian muslim yang berhijarah melalui sosial media. Mereka beranggapan bahwa hal-hal yang dimata menarik akan diikutinya. Lantas, jika direlevansikan dengan mukena syar'i syahrini yang memiliki kualitas high class, maka perlu perombakan pencantuman label halal. Lebih menguntungkan bagi semua jika label itu diganti dengan adanya label haram.

Dampak yang ditimbulkan karena adanya pencantuman label halal adalah merugikan pihak produsen yang masih pemula untuk menggeluti bisnis sandang. Walaupun sudah diberi label halal oleh Majelis Ulama Indonesia, konsumen 
harus mengetahui tata cara pemakain yang benar. Label halal pada sandang banyak yang beranggapan bahwa produk itu ada hanya untuk ekonomisasi keagamaan.

\section{Daftar Pustaka}

Lies Afroniyati, 2014,"Analisi Ekonomi Politik Sertifikasi Halal oleh Majelis Ulama Indonesia”, Yogyakarta, Jurnal Kebijakan dan Administrasi Publik.

Nurul, Istiqomah. 2016. "Mengungkap Mitos Simbol Halal pada Kerudung Zoya di Instagram”. Semarang. Skripsi, Jurusan Ilmu Komunikasi Fakultas Ilmu Sosial dan Politik Universtas Diponegoro.

Siti, Maemonah. 2017. "Pengaruh Merk dalam Labelisasi Halal Terhadap Keputusan Pembelian Produk Jilbab Zoya: Studi Kasus Pada Konsumen di Outlet Produk Jilbab Zoya Pamularsih Semarang”. Skripsi Program Studi Ekonomi Islam Fakultas Ekonomi dan Bisnis Islam Universitas Islam Negeri Walisongo Semarang.

Ikhsan, Abdullah. 2018. "Undang Undang No 33 Tahun 2014 Tentang Jaminan Produk Halal dan Tantangan Sekaligus Peluang Bagi Dunia Industri”. Jember.

Lembaga Pengkajian Pangan Obat obatan dan Kosmetika (LPPOM) Majelis Ulama Indonesia dikutip dari www.halal.mui.org pada tanggal 1 Juli 2019 pukul 15.25 wib 
Sejarah Majelis Ulama Indonesia (MUI) dikutip dari www.mui.or.id pada tanggal 1 Juli 2019 pukul 14.10 wib

Sofyan Hasan, "Kepastian Hukum Sertifikasi dan Labelisasi Halal Produk Pangan", Jurnal Dinamika Hukum, Volume 14 Nomor 2, 2 Mei 2014, Palembang: Universitas Sriwijaya.

Khoirul, Hadi dan Afifatul, Munawiroh. 2019. "Dari Fatwa Preventif Menuju Fatwa Advokatif: Menggagas Metodologi Penetapan Fatwa Majelis Ulama Indonesia Menggunakan Prinsip Keterbukaan Fatwa (Fath AzZari'ah) dan Kritik Terhadap Fatwa MUI yang Menggunakan Prinsip Pencegahan dalam Fatwa (Sadd Az-Zari'ah) yang Berkaitan dengan Hukum Keluarga”. Jember. Jurnal Fakultas Syariah IAIN Jember.

Yuli Mutiah Rambe dan Syaad Afifudin, 2012, "Pengaruh

Pencantuman Label Halal Pada Kemasan Mie Instan Terhadap Minat Pembelian Masyarakat Muslim”, Desember 2012, Jurnal Ekonomi dan Keuagan.

Dampak Produk Tanpa Label Halal Dalam Membuat Keputusan Pembelian Produk Kosmetik: Studi pada Konsumen Swalayan Aneka Jaya Ngaliyan Semarang, dikutip di walisongo.ac.id pada tanggal 3 Juli 2019 pukul 12.02 wib.

Fuad Mustafid, 2014, "Ketika Makkah Menjadi Las Vegas Agama, Politik, dan Ideologi”, Jakarta, PT Gramedia Pustaka Umum. 